\title{
The position of the augite syenite and pulaskite in the Ilimaussaq intrusion, South Greenland
}

HENNING SORENSEN

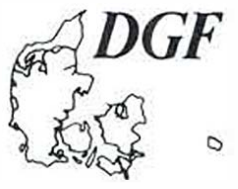

\begin{abstract}
Serensen. H.: The position of the augite syenite and pulaskite in the llimaussaq intrusion, South Greenland. Bull. geol. Soc. Denmark, vol. 27, Special issuc, np. 15-23, Copenhagen, July 30th 1978.

https://doi.org/10.37570/bgsd-1978-SI-03

The augite syenite is generally recognized as the earliest intrusive phase of the flimaussaq intrusion. lt has been proposed that the agpaitic nepheline syenites, which constitute the major part of the intrusion, are products of in situ differentiation of a primary augite syenitic magma. Recent field and laboratory investi-gations demonstrate. however. that there was a clear break between the consolidation of the augite syenite and the emplacement of the agpaitic rocks. The latter have most probably formed from a second pulse of magma injection and have been cmplaced by spalting off of rafts of augite syenite and other rocks from the walls and roof of the chamber.
\end{abstract}

Contribution to the Mineralogy of llimaussáq. No. 54.

Henning Sarensen, Institut for Petrologi, Oster Voldgade 10. DK'-1350 Kobenhavn K. Denmark. March Ist, 1978.

When preparing a contribution to a volume compiled in the honour of Professor Arne NoeNygaard one is left in a dilemma. His versatility and profound influence on the flourishing development of the geology in Denmark during more than three decades make the selection of a really relevant theme difficult. My own deliberations finally centered around the summer of 1946, the first field-season in West Greenland after the Second World War. That summer Professor Noe-Nygaard directed the programme of geological mapping of the south-west coast of Greenland which was initiated in the Precambrian metamorphic complexes around Holsteinsborg.

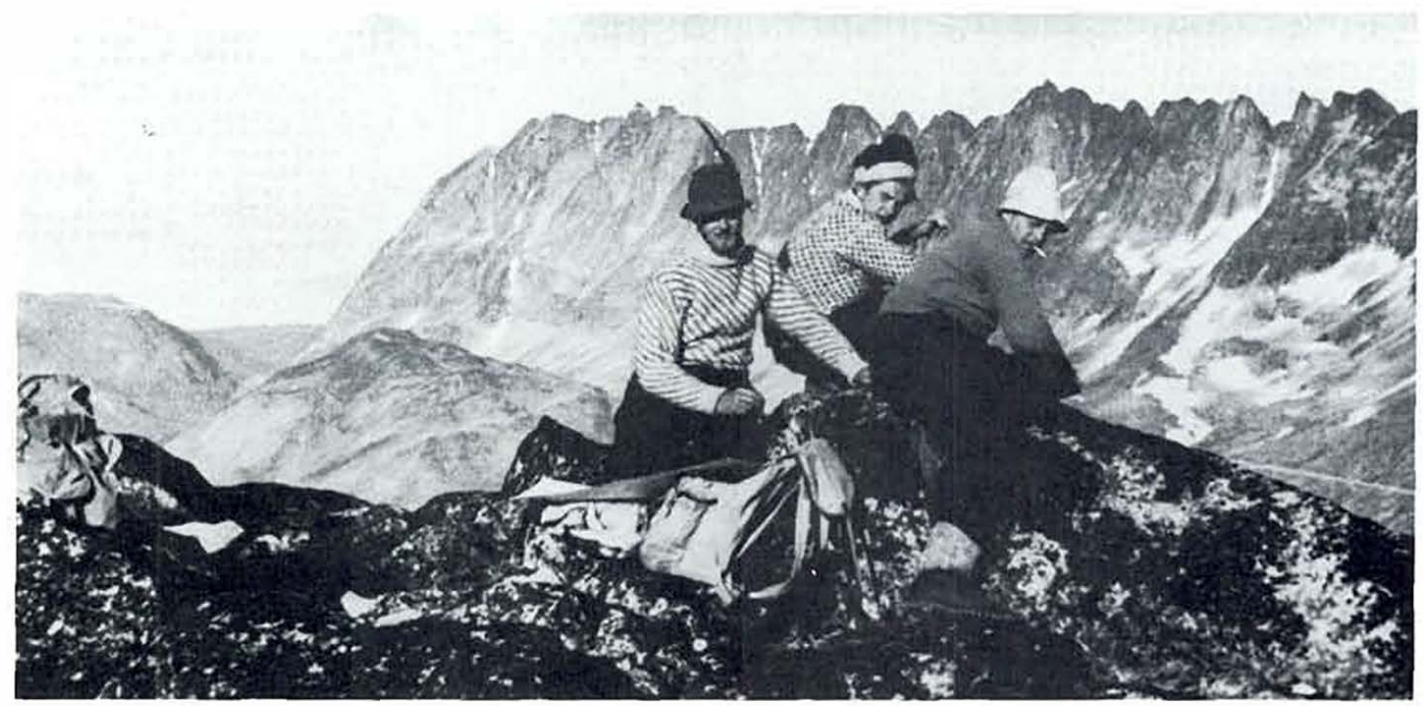

ligg. 1. Summis meeting on the 1. Sepr. 1946. Iriangiussan kangigdleq, alt. $908 \mathrm{~m}$, to the immediate west of the southern part of the llimaussat intrusion. which is seen in the low mountuins to the left (se'e also fig. 6). The mountuin ridge in the hackground is Kidtlasiat made up of Julianehaub granite. The persons from left to right are: Kinud Ellitsgaurd-Rasmussen, Hemning Sarensen and Arme Noe-Nogaard (R. Bagiad Phot.) 
At the end of the field-season he made a reconnaissance visit to the Ilimaussaq intrusion in South Greenland accompanied by Knud Ellitsgaard-Rasmussen. The late Richard Bøgvad, chief geologist in the Kryolitselskabet Øresund $\mathrm{A} / \mathrm{S}$, and I came down from Ivigtut to take part in this visit to the classical region (see fig. 1).
The Ilimaussaq intrusion, so admirably described by N.V. Ussing (1912), had attracted new interest in the years before the war. A great number of Soviet Russian papers made reference to the intrusion because of its similarities to the Khibina and Lovozero intrusions of the Kola peninsula. Wager and Deer (1939) in their classical "Skær-

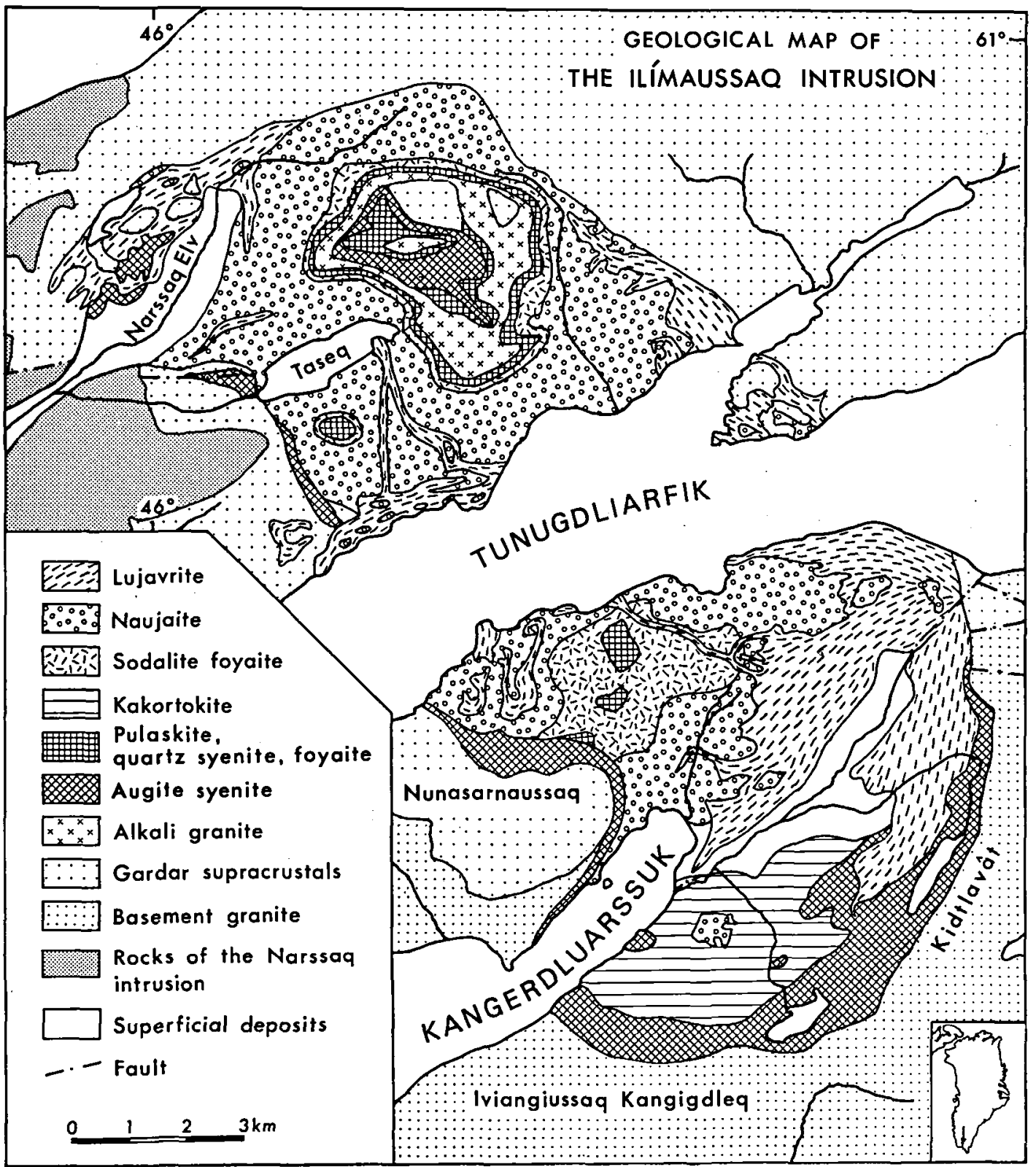

Fig. 2. Geological map of the llimaussaq intrusion (after $J$. Ferguson). 
Table 1. The major rock types of the Ilímaussaq intrusion

\begin{tabular}{|c|c|c|c|}
\hline Rock type & Texture, grain size & Essential minerals & Minor minerals \\
\hline augite syenite & $\begin{array}{l}\text { hypidiomorphic to } \\
\text { xenomorphic granular, } \\
\text { massive or banded, medium } \\
\text { to coarse }\end{array}$ & $\begin{array}{l}\text { alkali feldspar, fayalitic } \\
\text { olivine, ferrosalite }\end{array}$ & $\begin{array}{l}\text { titanomagnetite, apatite, } \\
\text { Ti-rich hastingsite, biotite }\end{array}$ \\
\hline $\begin{array}{l}\text { pulaskite and } \\
\text { heterogeneous } \\
\text { foyaite }\end{array}$ & $\begin{array}{l}\text { massive, medium to coarse, } \\
\text { platy feldspars }\end{array}$ & $\begin{array}{l}\text { alkali feldspar, hedenbergite, } \\
\text { katophorite, nepheline, } \\
\text { fayalite, alkali pyroxene }\end{array}$ & $\begin{array}{l}\text { apatite, titanomagnetite, } \\
\text { aenigmatite, biotite, } \\
\text { fluorite, eudialyte }\end{array}$ \\
\hline sodalite foyaite & massive, coarse & $\begin{array}{l}\text { alkali feldspar, nepheline, } \\
\text { sodalite, alkali pyroxene, } \\
\text { alkali amphibole }\end{array}$ & $\begin{array}{l}\text { fayalite, apatite, magnetite, } \\
\text { eudialyte, rinkite, fluorite }\end{array}$ \\
\hline naujaite & poikilitic, coarse & $\begin{array}{l}\text { sodalite, alkali feldspar, alkali } \\
\text { pyroxene, alkali amphibole }\end{array}$ & $\begin{array}{l}\text { eudialyte, rinkite, zeolites, } \\
\text { aenigmatite, nepheline }\end{array}$ \\
\hline kakortokite & $\begin{array}{l}\text { laminated, layered, } \\
\text { medium }\end{array}$ & $\begin{array}{l}\text { alkali feldspar, nepheline, } \\
\text { alkali amphibole, eudialyte }\end{array}$ & aenigmatite, rinkite, zeolites \\
\hline lujavrite & $\begin{array}{l}\text { laminated, fine; and } \\
\text { massive, layered, medium } \\
\text { to coarse }\end{array}$ & $\begin{array}{l}\text { microcline, albite, nepheline, } \\
\text { arfvedsonite, aegirine, } \\
\text { eudialyte }\end{array}$ & $\begin{array}{l}\text { sphalerite, steenstrupine, } \\
\text { monazite, sodalite, zeolites, } \\
\text { Li-mica }\end{array}$ \\
\hline
\end{tabular}

gaard Memoir", compared the augite syenite and the kakortokite of Ilimaussaq with respectively the border group and the layered series of the Skærgaard intrusion.

C. E. Wegmann (1938) in another classical paper dealing with the geology of Southwest Greenland also commented on the origin of the rocks of the Ilimaussaq "batholith". He advanced the view that the agpaitic rocks of Ilimaussaq were the results of metasomatic transformation of pre-existing volcanic and plutonic rocks. The pulaskite was for instance considered a metasomatised earlier syenite. The augite syenite was, according to Wegmann (1938: 78), limited to large faults on either side of Kangerdluarssuk and below Kidtlavât.

The views of Wegmann were a great challenge to our group in 1946, as transformistic ideas then prevailed in the mapping of the Precambrian of West Greenland. We had, however, difficulties with regard to the distinct contacts and other typically igneous features when walking over the excellent outcrops of the Ilimaússaq intrusion. In recollection of the impression created by this first visit to the famous region, I shall discuss some of the problems we encountered in 1947 namely the position of the augite syenite and the mode of emplacement of the agpaitic rocks in the light of the extensive studies carried out in the region since then.

\section{On the occurrence of augite syenite in the Ilimaussaq intrusion}

The augite syenite forms a marginal envelope along the west and south contacts of the intrusion and further occurs as larger masses in the roof zone and as inclusions in kakortokite and lujavrite at deper levels in the intrusion. The rock is of miaskitic affinity in contrast to the agpaitic nepheline syenites, which constitute the major part of the intrusion. For further information about the geology of the Ilimaussaq intrusion reference is made to fig. 2 , table 1 and the literature quoted in this paper.

All authors, who have discussed the position of the augite syenite in the Ilimaussaq intrusion, agree that this rock marks the first intrusive activity within the volume now occupied by the visible part op the intrusion. The augite syenite displays chilled contacts against the country rocks, which are Julianehaab granite and Gardar sandstone and volcanics (see e.g. Ussing 1912; Ferguson 1964, 1970). There are apophyses into the country rocks and the latter are chemically and 


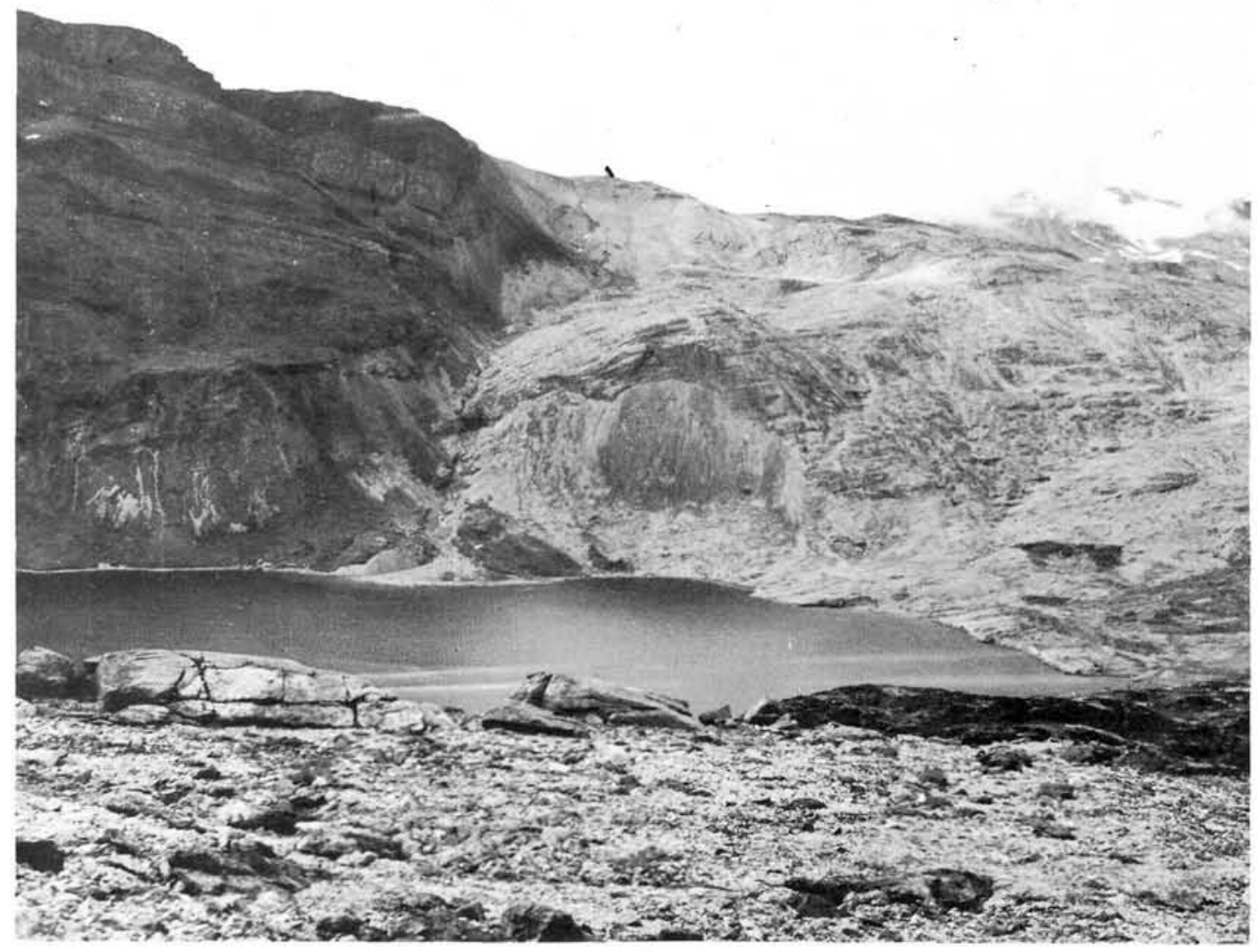

Fig. 3. The north side of the head of Kangerdluarssuk. The Jlimaussaq intrusion (to the right) is in contact with Julianehaab granite overlain by sandstone with sheets of dolerite in the Nunasarnaussaq mountain (to the left). The contact zone consists of augite syenite. The pulaskite of fig. 4 is found a few hundred metres from the contact near the top of this section through the llimaussaq intrusion which from bottom to top is made up of naujaite, sodalite foyaite, foyaite and pulaskite. The crumbling nature of the syenitic rocks is evident from the complete lack of vegetation ( $H$. Sørensen phot.). mineralogically altered near the contact (see e.g. Ferguson 1970).

The contact relations between the augite syenite and the agpaitic nepheline syenites are less distinct. The augite syenite is clearly older than the latter rocks since it forms inclusions in kakortokite and lujavrite and is intersected by veins of nepheline syenite pegmatites. Along contacts on kakortokite and naujaite there is, however, no development of a contact facies. The adjoining rocks are coarse-grained right up to the contact which in places is marked by a pegmatitic zone. Furthermore there is in the kakortokite in contact with augite syenite a pronounced disturbance of the layering at a distance of up to $100 \mathrm{~m}$ from the contact. This disturbed zone is rich in pegmatites (see Ussing 1912; Bohse et al. 1971).

According to Hamilton (1964) there is a distinct change in the mineralogy of the augite syenite in the Kangerdluarssuk region when passing from the marginal chill zone to the contact on the nepheline syenites. The quantity of nepheline, amphibole and unmixed alkali feldspar increases towards the nepheline syenites and near these rocks there are traces of eudialyte and sodalite. This is an indication of a trend of crystallization going from a near saturated to a distinctly silica-undersaturated mineral assemblage.

The relationship between augite syenite and the pulaskite of the upper part of the intrusion presents a special problem. Ussing (1912: 341) re- 
ports that these two rocks come next to each other on the north-east side of Nunasarnaussaq in such a way that no boundary has been detected. He considered the pulaskite to be a remnant of the original syenite, which at one time filled the reservoir, or perhaps a product of reaction between the agpaitic magma and the magma responsible for the formation of the alkali granite, which may originally have covered a great deal of the area of the intrusion. It should at this place be pointed out that the contact relations in the Nunasarnaussaq area are obscured by the strongly crumbling nature of the various syenites and nepheline syenites (fig. 3 ).

\section{The petrological role of the augite syenite}

Ussing (1912: 327) proposed that the augite syenite was earlier than the nepheline syenites but still warm when it was intruded by the nepheline syenite magma. Ussing thus distinguished distinct pulses of magma injection.

Sørensen (1958), Ferguson (1964, 1970), Engell (1973) and Macdonald (1974: 452) examined the possibility that the syenites and nepheline syenites of the Ilimaussaq intrusion were formed by in situ differentiation of a primary augite syenitic magma. Evidence for such an evolution has been presented by Upton (1964) for the Hviddal composite dyke to the west of Ilimaussaq in which there is a gradual transition from augite syenite to sodalite foyaite.

According to Sørensen (1958) there was a build up of volatiles in the magma to such an extent that for instance the pulaskite, which is chemically close to the augite syenite, could form from a syenitic magma. enriched in volatiles near the top of the intrusion. Ferguson $(1964,1970)$, on the other hand, regarded the pulaskite as a product of reaction between the evolving primary syenitic magma and an alkali granitic magma. Engell (1973) demonstrated that a formation of agpaitic nepheline syenites from a primary augite syenitic magma, now represented by the chilled zone, by means of crystal fractionation could only take place when $90-95 \%$ of the volume of the primary magma had consolidated, which means that the hidden part of the intrusion extends down to the base of the crust.

More recent field and laboratory studies have, however, strengthened Ussing's original idea of separate pulses of magma as is discussed by Sørensen (1969 a, 1970), Blaxland, von Bremen \& Steenfelt (1976), Larsen (1976) and Emeleus \& Upton (1976).

Blaxland et al. (1976) concluded from field studies, $\mathrm{Rb}-\mathrm{Sr}$ whole rock isochron dating and initial ${ }^{87} \mathrm{Sr} /{ }^{86} \mathrm{Sr}$ ratios that the augite syenite and the agpaitic nepheline syenites formed two separate intrusive events, but in close succession. The isotopic age based on all the examined specimens was determined to $1188 \pm 30$ m.y. (initial ${ }^{87} \mathrm{Sr} /{ }^{86} \mathrm{Sr}$ ratio $=0.7060 \pm 0.0021$ ), the age of all specimens with the exception of augite syenite was $1168 \pm 21$ m.y. (initial ${ }^{87} \mathrm{Sr} /{ }^{86} \mathrm{Sr}=0.7096 \pm 0.0022$ ). This indicates that the augite syenite as other syenites in the Gardar Province may be of a primitive mantle origin.

Larsen (1976) has demonstrated marked discontinuities in the mafic minerals of the rocks of llimaussaq which may indicate several intrusive phases: 1 . augite syenite, 2 . a peralkaline undersaturated magma which gave rise to the pulaskite to naujaite series. The kakortokite and lujavrites may be evolved members of this series or products of crystallization of independent magmas.

\section{The petrological role of the pulaskite}

The position of the pulaskite is clearly of crucial importance for the understanding of the evolution of the Ilimaussaq intrusion. It forms the uppermost part of the layered sequence of agpaitic nepheline syenites being underlain by successively foyaite, sodalite foyaite, naujaite, lujavrite and kakortokite in the visible part of the intrusion. It is in places overlain by alkali granite from which it is separated by a thin sheet of quartz syenite. The position of this granite is still uncertain. The southernmost occurrences appear to form xenoliths in the pulaskite (Blaxland et al. 1976).

The contact between pulaskite and foyaite is gradual to sharp, the inch-scale layering of the pulaskite being parallel to the contact. In places the two rocks appear to interfinger in an intricate way. The pulaskite is by most authors regarded as the first rock to crystallize from the magma which by consolidation gave the succession pulaskite, foyaite, sodalite foyaite and naujaite (see e.g. Sørensen $1969 \mathrm{~b}$ and Larsen 1976). 


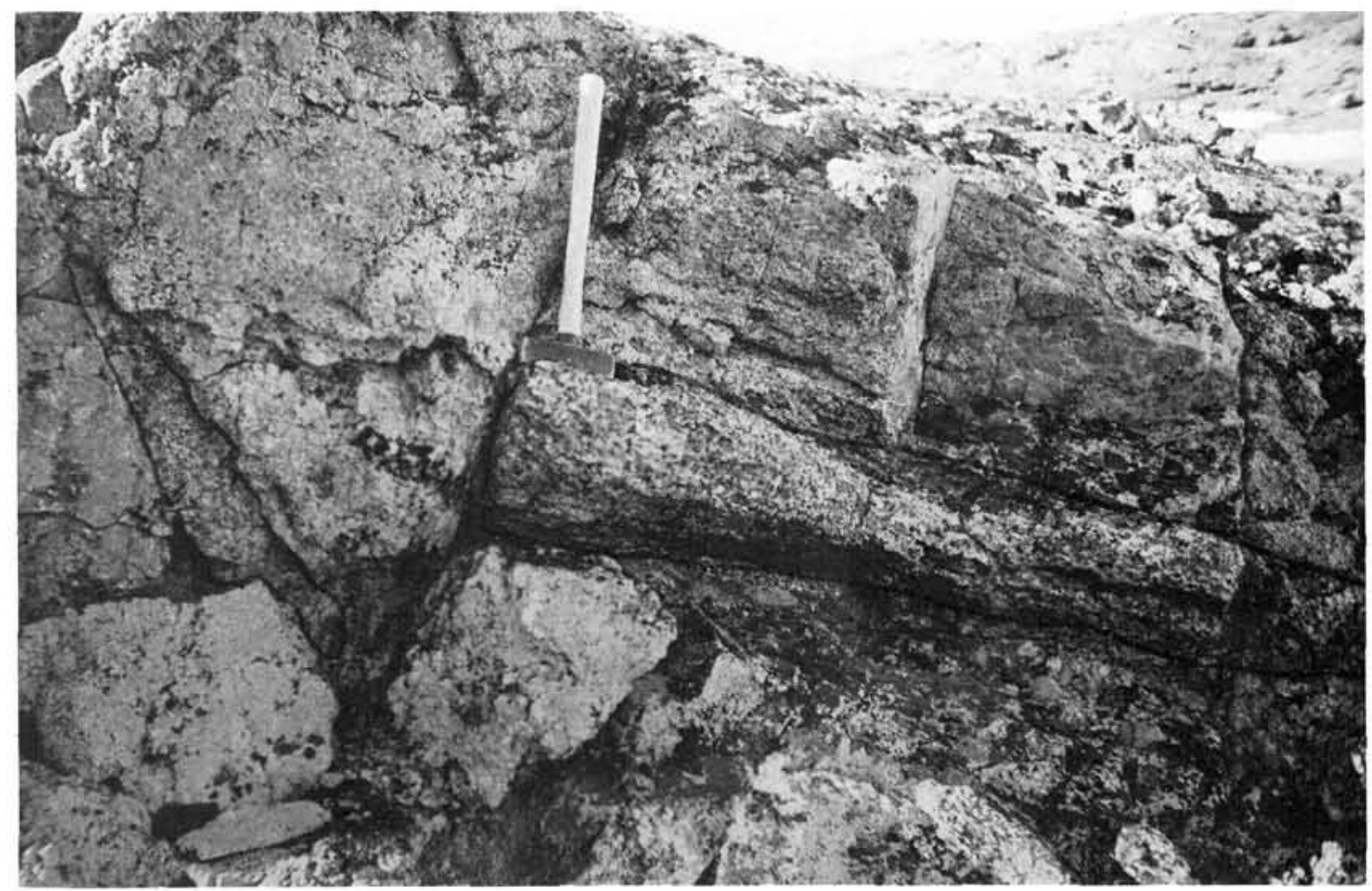

Fig. 4. Angular inclusions of augite syenite in pulaskite. Alt. about $550 \mathrm{~m}$. The locality is situated to the east of Nunasarnaussaq. The shape of the inclusions is emphasized with black ink (H. Serensen phot.).

In 1972, Agnete Steenfelt and the author observed angular inclusions of augite syenite in the pulaskite to the east of Nunasarnaussaq at an altitude of about $550 \mathrm{~m}$ (fig. 4). Later that summer, Steenfelt found similar inclusions at other localities in the same region. She also observed a sharp contact between pulaskite and the marginal augite syenite, both rocks being of normal grain size right up to the contact. The marginal augite syenite is intersected by feldspathic pegmatites which could be off-shoots from the pulaskite.

An inclusion of augite syenite in pulaskite was examined in a thin section of G.G.U. sample No. 150775. The inclusion is distinctly augite syenitic with regard to texture and mineralogy. The anhedral alkali feldspar grains show interfingering grain boundaries, the mafic minerals form clusters. The minerals are alkali feldspar, fayalitic olivine, brownish augite with green margins and in places rimmed and penetrated by brown amphibole, titanomagnetite, apatite and minor biotite, fluorite and some unidentified minerals. This rock shows signs of recrystallization and partial melting. The alkali feldspar is partly crypto- to microperthitic, partly unmixed to independent grains of albite and potash feldspar. In the latter case the potash feldspar is often rich in vermicular inclusions along contacts on albite and generally orientated more or less perpendicular to the grain boundaries. The minerals have not yet been studied by the electron microprobe and the vermicular phase is still unidentified. Small grains of fluorite occur between the two feldspars. These features are not seen in the augite syenite outside the pulaskite. They may be products of transformation caused by the pulaskitic magma and perhaps results of partial fusion. The Kûngnât syenites, which are fairly similar to the augite syenite in question, begin to melt at about $700^{\circ} \mathrm{C}$. and $2 \mathrm{k}$-bar waterpressure in such a way that some amphibole, biotite, quartz and feldspar melt $10-30^{\circ} \mathrm{C}$. above the solidus (McDowell \& Wyllie 1971). The transformation mentioned above is in strong contrast to that of the inclusions of augite syenite in the 


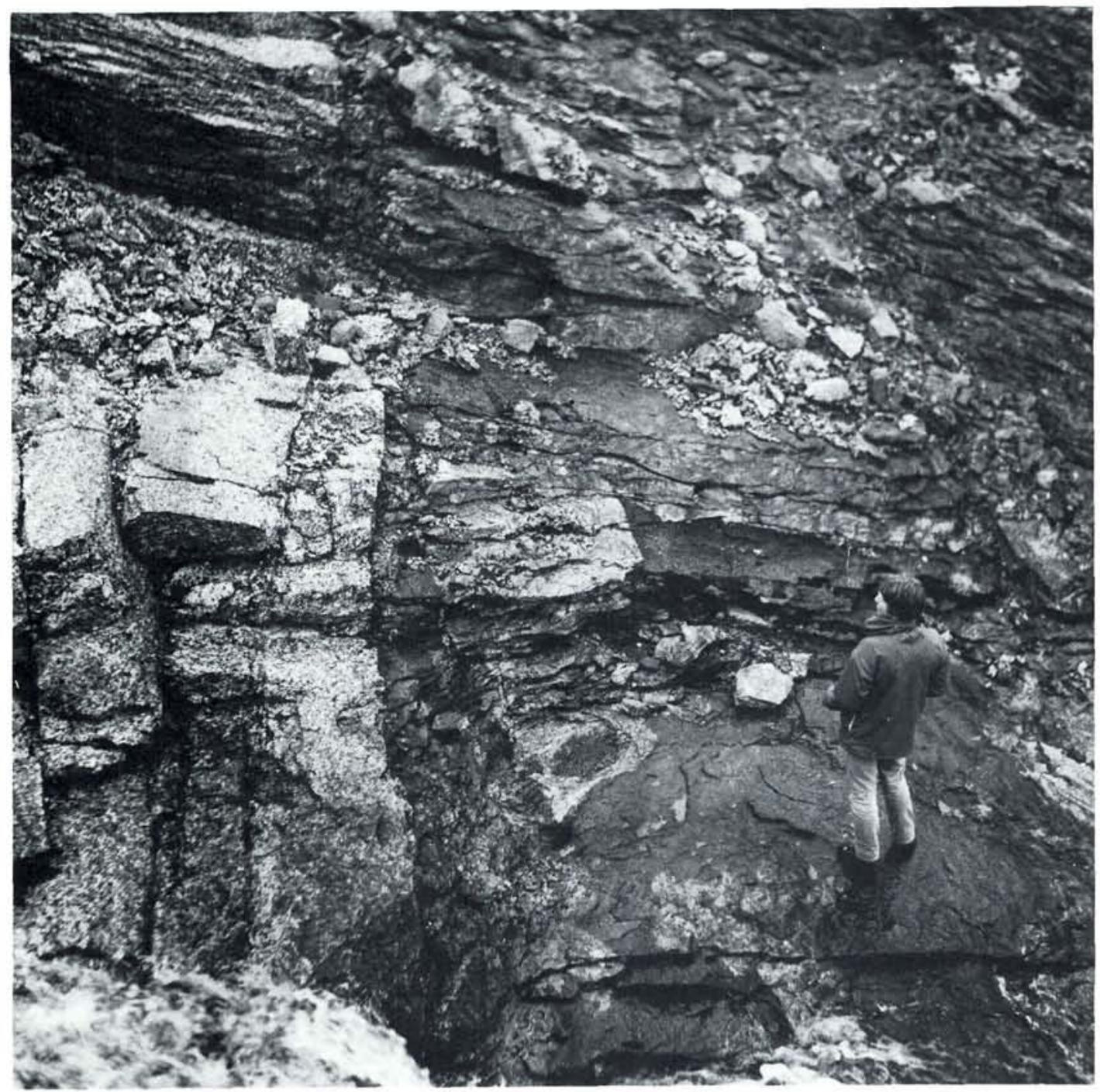

Fig. 5. The southern contact of the kakortokite. To the left augite syenite cut by parallel zones of crushing. To the right kakortokite with angular inclusions of augite syenite. Alt. $400 \mathrm{~m}$, side river to Lakse Elv. Kangerdluarssuk (H. Sørensen phot.).

kakortokite and lujavrite which are hydrothermally altered (see e.g. Bohse et al. 1971).

\section{Mode of emplacement of the agpaitic rocks}

The elongated, dyke-like shape of the xenoliths shown in fig. 4 is typical of the way of the spalling off of fragments of augite syenite along the con- tacts on the agpaitic rocks. Fig. 5, for instance, shows that augite syenite in contact with kakortokite is intersected by zones of crushing which are parallel to the contact. The kakortokite magma appears then to have been emplaced by loosening of rafts of augite syenite (and naujaite) along the zones of crushing which explains the shape of the xenoliths. Large rafts of augite syenite, naujaite and foyaite in the central part of the kakortokite practically all occur in the 


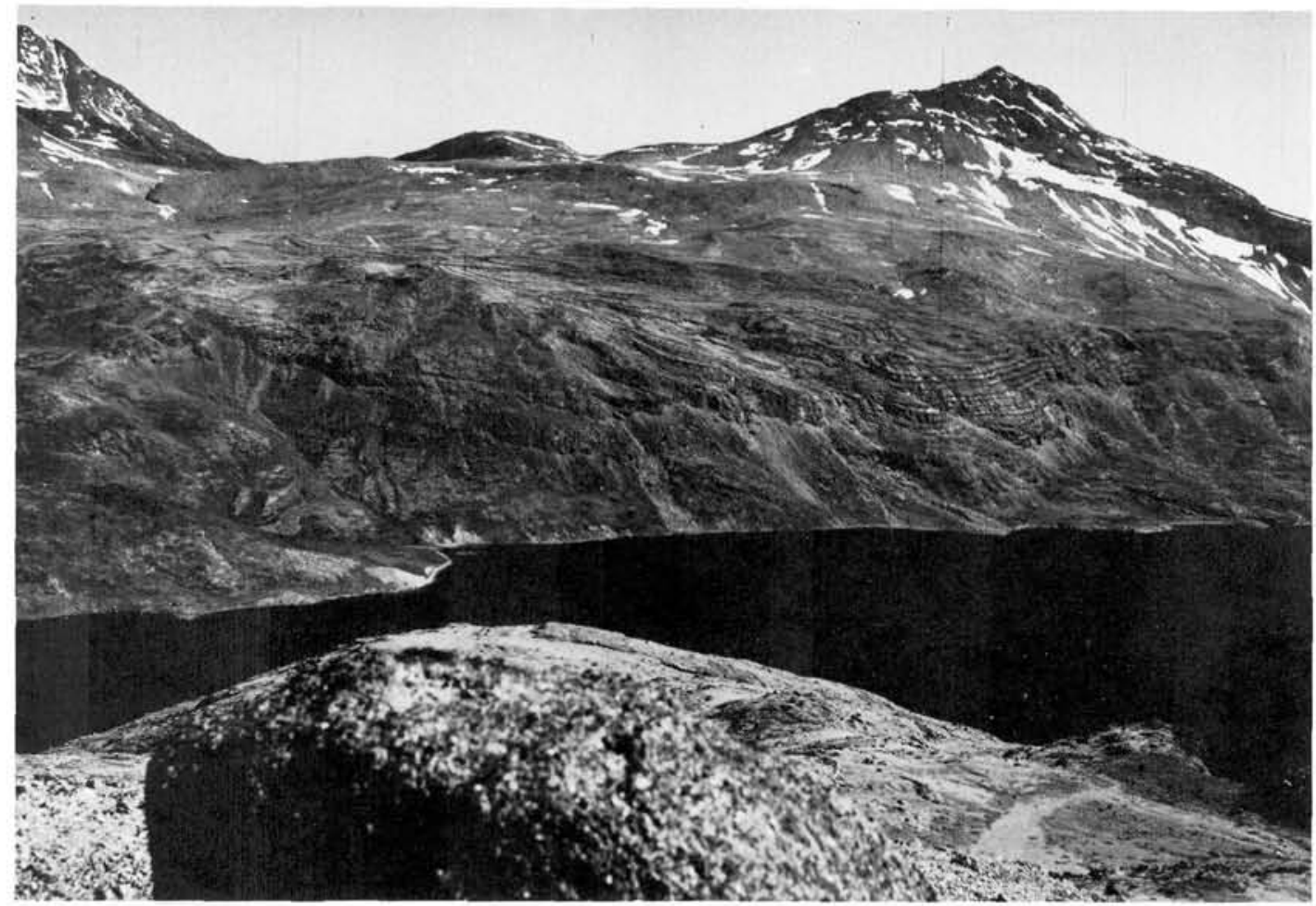

Fig. 6. The south coast of Kangerdluarssuk. In centre layered kakortokite in the Kringlerne plateau. In the background the country rock of Julianehaab granite in the Iviangiussaq mountain (see fig. 1). The structureless rock below the snow on the slope of Iviangiussaq is augite syenite (H. Sørensen phot.).

layer unit +3 corresponding to a major roof collapse (Bohse et al. 1971).

Large masses of naujaite along the contacts between augite syenite and kakortokite to the south of Kangerdluarssuk may be considered in the light of the mineralogical discontinuities between naujaite and kakortokite which indicate a younger age of the latter rock (Larsen 1976) fig. 6. This is also apparent from the inclusions of naujaite seen in the kakortokite (Bohse et al. 1971). The magma from which the kakortokite and at least some of the lujavrites consolidated may thus have intruded an already consolidated naujaite.

\section{Concluding remarks}

Returning to the challenge confronting the visitors to the intrusion in 1946 it is now clear that the relationship between the rocks of the intrusion is not caused by boudinage and metasomatic transformations as proposed by Wegmann in his provoking and inspiring 1938 memoir, but by successive injections of magmas. The studies since 1955 have further demonstrated that Ussing's interpretation from 1912 is still valid with regard to the mode of emplacement by stoping processes and to the succession and formation of most of the rocks of the intrusion. Augite syenite crystallizing at greater depths may still be considered a possible source of the agpaitic rocks. A geophysical investigation of the depth of the Ilimaussaq intrusion and the properties of the underlying crustal materials may contribute to an answer of this problem. Heat flow studies in the region (Saśs et al. 1972) indicate a shallow depth of the intrusion and an underlying crust made up of material which is extremely low in radioactive substances. The very scarce gravity data may fit 
a model according to which the Ilimaussaq intrusion is underlain by rather dense rocks (Forsberg \& Rasmussen, in press). The presence of xenoliths of anorthosite in many of the Gardar rocks, including the augite syenites of Ilimaussaq (Bridgwater and Harry, 1968), may be evidence of differentiating basic Gardar magmas at greater depths, from which not only augite syenite, but also various types of alkaline rocks may have been derived (cf. Berthelsen \& Noe-Nygaard 1965; Upton 1974).

\section{Dansk sammendrag}

Ilimaussaq-intrusion, som forst blev beskrevet af N. V. Ussing (1912), er hovedsagelig opbygget af peralkaline nefelinsyeniter. Ussing kaldte denne type nefelinsyeniter, der bl.a. er karakteriseret af en stor rigdom pá sjæaldne mineraler, for agpaitisk. Ilimaussaqs agpaitiske bjergarter udgør en lagdelt intrusion, som øverst består af den svagt alkaline nefelinsyenit, pulaskit, nederst af ekstremt peralkaline nefelinsyeniter, sásom naujait, kakortokit og lujavrit. Disse bjergarter er pá siderne og i toppen omgivet af et ufuldstændigt hylster af augitsyenit. Intrusionens bund er ukendt.

Ussing mente, at augitsyeniten var dannet $i$ en første fase af magmainjektion, mens de agpaitiske bjergarter blev til under en senere fase. Ud fra petrologiske kriterier mente Sørensen (1958), Ferguson (1964) og Engell (1973), at de agpaitiske bjergarter er afledt af et augitsyenitisk magma ved ekstrem magmatisk differentiation i et stort magmakammer, langs randen af hvilket augitsyenit størknede.

De nyeste undersøgelser, bl.a. af Sr-isotop-forhold og Rb-Srdatering (Blaxland m.fl., 1976) og af bjergarternes indhold af pyroxener og amfiboler (Larsen, 1976), har bestyrket Ussings oprindelige opfattelse af flere adskilte magmainjektioner. Denne opfattelse bestyrkes yderligere ved opdagelsen af indeslutninger af augitsyenit $i$ pulaskit $i$ den sydlige del af intrusionen (figs. 3,4).

De agpaitiske magmaer har skaffet sig plads gennem afskalning af flager af de ældre bjergarter (fig. 5).

\section{References}

Berthelsen, A. \& Noe-Nygaard, A., 1965: The Precambrian of Greenland. In: Rankama, K. (ed.) The Precambrian 2, 113-262. New York: Interscience.

Blaxland, A. B., Breemen, O. van \& Steenfelt, A., 1976: Age and origin of agpaitic magmatism at Ilimaussaq, South Greenland: Rb-Sr study. Lithos 9: 31-38.

Bohse, H., Brooks, C. K. \& Kunzendorf, H., 1971: Field observations on the kakortokites of the Ilimaussaq intrusion, South Greenland, including mapping and analyses by portable X-ray fluorescence equipment for zirconium and niobium. Rapp. Grenlands geol. Unders. 38: $43 \mathrm{pp}$.

Bridgwater, D. \& Harry, W. T., 1968: Anorthosite xenoliths and plagioclase megacrysts in Precambrian intrusions of South Greenland. Bull. Gronlands geol. Unders. 77 (also Meddr Gronland 185 (2)): 243 pp.

Emeleus, C. H. \& Upton, B. G. J., 1976: The Gardar period in southern Greenland. In: Escher, A. \& Watt, W. (eds.): Geology of Greenland, Geol. Surv. of Greenland, 153-181.
Engell, J., 1973: A closed system crystal-fractionation model for the agpaitic Ilimaussaq intrusion, South Greenland, with special reference to the lujavrites. Bull. Geol. Soc. Denmark 22: 276-302.

Ferguson, J., 1964: Geology of the Ilimaussaq alkaline intrusion, South Greenland. Bull. Granlands geol. Unders. 39 (also Meddr Grenland 172 (4)): $82 \mathrm{pp}$.

Ferguson, J., 1970: The significance of the kakortokite in the evolution of the Ilimaussaq intrusion, South Greenland. Bull. Gronlands geol. Unders. 89 (also Meddr Grenland $190(1)): 193 \mathrm{pp}$.

Forsberg, R. \& Rasmussen, K. L., (in press): Gravity and rockdensities in the Ilimaussaq area, South Greenland. Rapp. Gronlands geol. Unders. Report of activities 1977.

Hamilton, E. I., 1964: The geochemistry of the northern part of the Ilimaussaq intrusion, S.W. Greenland. Bull. Gronlands geol. Unders. 42 (also Meddr Gronland 162 (10)): $104 \mathrm{pp}$.

Larsen, L. M. 1976: Clinopyroxenes and coexisting mafic minerals from the alkaline Illimaussaq, intrusion, South Greenland, J. Petrology 17: 258-290.

Macdonald, R., 1974: The role of fractional crystallization in the formation of the alkaline rocks. In: Sørensen, H. (ed.): The Alkaline Rocks, 442-459. London: Wiley.

McDowell, S. D. \& Wyllie, P. J., 1971: Experimental studies of igneous rock series: the Kûngnât syenite complex of South-west Greenland. J. Geol. 79: 173-194.

Sass, J. H., Nielsen, B. L., Wollenberg, H. A. \& Munroe, R. J., 1972: Heat flow and surface radioactivity at two sites in South Greenland. J. Geophys. Res. 77: 6435-6444.

Sørensen, H., 1958: The Ilimaussaq batholith. A review and discussion. Bull. Gronlands geol. Unders. 19 (also Meddr Gronland $162(3)$ ): $48 \mathrm{pp}$.

Sørensen, H., 1969 a: On the magmatic evolution of the alkaline igneous province of South Greenland. Rapp. Gronlands geol. Unders. 7: $19 \mathrm{pp}$.

Sørensen, H., 1969 b: Rhythmic igneous layering in peralkaline igneous intrusions. Lithos 2: 261-283.

Sørensen, H., 1970: Internal structures and geological setting of three agpaitic intrusions - Khibina and Lovozero of the Kola Peninsula and Ilimaussaq, South Greenland. Canadian Miner. 10: 299-334.

Upton, B. G. J., 1964: The geology of Tugtutôq and neighbouring islands, South Greenland. IV. The nepheline syenites of the Hviddal composite dyke. Bull. Gronlands geol. Unders. 48 (also meddr Gronland 169 (3)): 49-80.

Upton, B. G. J., 1974: The alkaline province of South-West Greenland. In: Sorensen, H. (ed.): The Alkaline Rocks, 221-238. London: Wiley.

Ussing, N. V., 1912: Geology of the country around Julianehaab, Greenland. Meddr Grenland 38: $376 \mathrm{pp}$.

Wager, L. R. \& Deer, W. A., 1939: Geological investigations in East Greenland. III. The petrology of the Skaergaard intrusion, Kangerdlugssuaq, East Greenland. Meddr Grenland 105 (4): $335 \mathrm{pp}$.

Wegmann, C. E., 1938: On the structural divisions of southern Greenland. Meddr Grenland 113 (4): 148 pp. 